\title{
Preparing the Playing Field. Climate Club Governance of the G20, the Climate and Clean Air Coalition and the Under2 Coalition
}

Charlotte Unger ( $\nabla$ charlotte.unger@iass-potsdam.de )

Institute for Advanced Sustainability Studies eV https://orcid.org/0000-0003-1095-5700

\section{Sonja Thielges}

Institute for Advanced Sustainability Studies eV

\section{Research Article}

Keywords: international climate policy, climate governance, climate clubs, minilateral policy approaches, case study

Posted Date: February 8th, 2021

DOl: https://doi.org/10.21203/rs.3.rs-178463/v1

License: (우 (i) This work is licensed under a Creative Commons Attribution 4.0 International License. Read Full License

Version of Record: A version of this preprint was published at Climatic Change on August 16th, 2021. See the published version at https://doi.org/10.1007/s10584-021-03189-8. 


\section{Abstract}

International climate policy is increasingly shaped by alternative forms of governance. Coalitions of national, subnational and/or non-state actors have the potential to address the global challenge of climate change beyond the United Nations Framework Convention on Climate Change (UNFCCC) process. While initially such 'clubs' spurred hope that they could be an option to achieve climate action more effectively than the UNFCCC, more recently their role has been seen as preparing and orchestrating climate policy. In spite of its conceptual proliferation, literature on climate clubs stops short in examining practical evidence and conducting analyses beyond categorization and labelling of climate clubs. This article aims at contributing to filling this gap with a comparative perspective on three specific governance initiatives that act on different governance levels: The G20, the Climate and Clean Air Coalition (CCAC) and the Under2 Coalition. What contribution do these club-like initiatives make to global climate governance and how does it relate to existing structures such as the Paris Agreement and the UNFCCC process?

Our paper applies central aspects of clubs research, namely membership, public goods, and the provision of additional benefits as an analytical framework to examine the three cases. We find that these club initiatives, though highly diverse in their origin and membership, make a similar contribution to international climate governance. Their largest contribution lies in preparing emissions reductions through raising awareness, orchestrating different actors and actions, and establishing a large cooperation network. They complement the UNFCCC and especially the Paris Agreement.

\section{Introduction}

The development of the international climate policy landscape over the first two decades of the 21st century leads to two observations: First, the amount of efforts and actors has increased; second, notwithstanding, the realized and promised actions to mitigate climate change are far from being sufficient. A vast number of policies, regulations and initiatives, producing manifold responses to the challenge of climate change have emerged. By 2017, national climate strategies or regulations addressed about $70 \%$ of worldwide greenhouse gas emissions (GHG) (lacobuta et al., 2018). Within this realm, the number of actors in global climate governance has multiplied and diversified; all governmental levels, but also diverse interand non-governmental actors and transnational alliances play a role. Many non-traditional climate policy actors have also taken up climate change as a major topic; for example, the G20 and G7 have included climate change on their agenda. Nevertheless, these efforts remain insufficient: The process of the Paris Agreement (PA) under the United Nations Framework Convention on Climate Change (UNFCCC), adopted in 2015 , faces major shortcomings. Signatories have committed to national efforts to combat climate change in 'Nationally Determined Contributions' (NDCs) and jointly set a goal of keeping global warming at 'well below $2{ }^{\circ} \mathrm{C}$ '. Even though many of the above-raised aspects are conducive to the goals of the PA, all NDCs combined would produce only one third of the necessary emission reductions so far (UN Environment, 2018).

A growing body of research has evolved that takes stock of the diverse climate policy landscape. One approach to examine these innovative governance initiatives is the climate clubs concept, which builds on 
the idea that a smaller group of actors can make more, or different progress in international climate governance than multilateral fora, such as the United Nations (UN). While initially such 'clubs' had spurred hope that they could be an option to achieve climate action quicker and more effectively than the UNFCCC, more recently, they have been seen as building blocks, having a role in preparing the implementation of emissions reductions and orchestrating climate governance actions (Falkner et al., 2010, Stewart et al., 2017). However, we find that there is a research gap when it comes to exploring the nature of their governance contribution. Literature rarely provides in-depth case studies on climate clubs and misses taking into account knowledge from the political practice.

In order to contribute to filling these gaps, we provide a meta-comparative view on three different cases: the G20, a high-level forum comprised of the governments of 19 important industrialized and emerging economies that features a climate and energy workstream; the Climate and Clean Air Coalition (CCAC), a partnership of 149 state and non-state partners established to slow the rate of near-term global warming; and the Under2 Coalition (U2C), a coalition over 2020 mostly subnational governments, which aims at increasing subnational emission reduction commitments in line with the PA The paper starts with a brief perspective on the evolvement of the polycentric governance landscape and then reflects on existing research on climate clubs. It builds up on the analytical framework of Unger et al. (2020), which proposes three criteria to examine climate club like initiatives: 1. membership, 2. public goods and 3. additional (club) goods. Applying these criteria on the three named initiatives we ask: how can such initiatives make additional contributions to the achievement of the PA and what is their value for global efforts to mitigate climate change?

For each case we provide an analysis of these three criteria and then discuss the results from a comparative perspective. Even though some research has been carried out on the climate policy activities of the G20, the much younger initiatives, CCAC and U2C, lack substantial academic investigation. This paper further aims at contributing to filling this gap.

\section{Setting the scene: the international climate policy landscape is polycentric}

The development of our multifaceted climate governance landscape cannot be understood fully without having a look at its central governing process under the UNFCCC. The devasting Copenhagen conference in 2009 (Conference of the Parties (COP) 15) received much scientific attention, as it ended without an agreement to succeed the Kyoto Protocol. It led to what scholars called a 'gridlock' in the international negotiations (Victor and Keohane, 2010). While this situation, on the one hand, led to frustration with the multilateral process, it has also initiated a diversification of policy efforts: Climate governance activities have become multifaceted and especially those activities that do not have a strict legal character, such as climate strategies, plans and non-binding climate programs and mechanisms, have increased. Within this realm, the number of actors active in climate governance has also multiplied and diversified. Climate governance today goes far beyond national and international categories. It has become transnational (Abbott, 2012, Chan et al., 2018) in many senses and on several axes: Actors range from local to international governmental authorities and civil society groups, to the private sector, as well as many overarching transnational alliances. A highly complex and polycentric, but also fragmented international 
climate policy regime has evolved (Victor and Keohane, 2010, Ostrom, 2010, Pattberg and Widerberg, 2017, Biermann et al., 2009). In this context, research has focused on bottom-up initiatives that lead to a decentralized regulatory system (Victor and Keohane, 2010). The idea behind this is that minilateral actors can make a greater effort for climate change mitigation through reducing the bargaining complexity of large fora such as the UNFCCC (Victor, 2015).

In the realm of the ongoing process under the UNFCCC and the adoption of the PA, the multifaceted climate policy landscape bears the advantage of more opportunities to provide additional and complementary climate change mitigation activities.

\section{How innovative governance initiatives and climate clubs tackle climate change}

Research has evolved on the role of innovative transnational and non-state governance initiatives, on how they complement the UNFCCC process and how they contribute to closing the gap between national commitments and overall targets of the PA (Graichen et al., 2016, Hermwille, 2018, Chan et al., 2018, Michaelowa and Michaelowa, 2017). Several studies have found 'orchestration' as one of the main achievements: This refers to a situation where climate policy efforts and actors are coordinated, initiated, directed or managed in a rather soft manner by the UNFCCC or other inter- and transnational actors (Abbott et al., 2015, Hermwille, 2018, Chan et al., 2018). Other authors have recognized the function of bridging and overcoming fragmentation that transnational partnerships can have by facilitating dialogue in spite of persistent political conflicts (Gupta et al., 2016).

Stewart et al. (2017) examine how different governance innovations can progress the implementation of the PA. They frame a 'building blocks approach': Multiple transnational mechanisms that include different sectors, themes or measures related to climate change form blocks as part of a larger strategy. The building blocks have the potential to broaden the efforts countries committed to under the UNFCCC. Among the types of collaborations Stewart et al. (2017) describe in their building blocks concept are climate clubs. These climate clubs, accordingly, need not be primarily concerned with climate issues, but subgroups of actors within an organization may support mitigation activities and link them to existing targets of the organization in a so-called linking strategy (Stewart et al., 2017).

Climate clubs can, in theory, make more progress towards a broader goal than multilateral fora, through being more ambitious in creating optimal outcomes, such as goods and cooperation (Buchanan, 1965, Olson, 1971, Victor and Keohane, 2010, Victor, 2015). From an economics' perspective, Buchanan (1965) describes clubs as a special form of cooperation, producing private and public goods. The concept has been applied to trade, environment and climate-related issue areas (Prakash and Potoski, 2007, Abbott, 2012).

Climate clubs or clubs that treat climate change issues are often seen in some relationship with the UNFCCC process. Initially, the discussion evolved around whether clubs have a complementing, bypassing or conflicting relationship with the UNFCCC (Widerberg and Stenson, 2013). However, more recently research has tended to recognize a more positive relationship: Categorizations range from clubs as a 
"friendly competitor" (Victor, 2015: 8) to the UNFCCC process to a clear complementing role to direct cooperation (Widerberg and Stenson, 2013).

From a conceptual perspective, many climate club approaches are rooted in the idea of forming a 'coalition of the willing' (Hale, 2011), referring to a group of like-minded actors cooperating on a specific topic. Approaches on clubs have in common that they assume that a small group of relevant players can develop solutions on a global level (Falkner, 2016, Nordhaus, 2015). In this sense, Hovi et al. (2017) define a climate club as "(...) any international actor (country) group that (1) starts with fewer members than the UNFCCC has and (2) aims to cooperate on climate change mitigation" (Hovi et al., 2017:2). Nordhaus adds that "A club is a voluntary group deriving mutual benefits from sharing the costs of producing an activity that has public-good characteristics" (Nordhaus, 2015: 1340). Green (2015) introduced pseudo-clubs as a third category, which refers to initiatives with non-binding standards, without compliance control. As a synthesis, Stewart et al. (2017) propose to understand the climate club concept as a continuum of club-like arrangements, which includes the whole range from classic economic clubs to looser forms of coalitions.

\section{Analytical Approach And Methodology}

Our approach builds on Stewart et al. (2017) in taking into account different types of clubs that tackle climate change mitigation - either as a central focus or as one aim among others. Stewart et al (2017) suggest clubs can incentivize additional emissions reductions to those promised under the UNFCCC through shifting the incentive structure towards non-climate benefits, for example reduced energy costs. This perspective can be complemented with Victor's (2015) idea that clubs develop solutions for hard or 'niche' topics and help these solutions to be used by a larger array of actors. Clubs as building blocks help to implement and increase the effectiveness of the PA and may support the increase of ambition in future updates of commitments (Stewart et al., 2017). This idea of building blocks combines the clubs conceptualization with research on other minilateral and transnational governance initiatives and their contribution to the UNFCCC and PA. Making use of this approach, in the following paragraphs, we combine some common understandings from existing research on climate clubs with knowledge on transnational actors. Using an analytical framework developed in Unger et al. (2020), we study three relevant climate club characteristics and how they are manifested in practice: (1) club membership and size, (2) public goods; (3) additional benefits or 'club goods'. Based on this framework, we analyze and compare three different cases: the G20, the CCAC and U2C. This qualitative analysis can help to understand how, why and what type of progress a climate club makes in international climate policy. It puts emphasis on the exploration of the political practice, including, for instance governance contributions other than emissions reductions or raising awareness and support, in a field where quantification is difficult. This study can thus be seen as complementary to quantitative evaluations of the impact of climate clubs. We elaborate on our three analytical categories in the following paragraphs.

Club membership and size: In order to progress climate change mitigation efforts, a club should have 'relevant members'. Most literature agrees that a club must include the 'right' or 'key' actors (Victor, 2015, Falkner, 2016, Hovi et al., 2017) and is exclusive to non-members (Nordhaus, 2015). Relevance is usually determined based on the problem, and is therefore rooted in the notion of a 'critical mass' for a problem 
solving activity. In this sense, members can be relevant in terms of GHG emissions (Naím, 2009, Hovi et al., 2017) but also through their vulnerability to climate change or their capability from an economic, political or knowledge perspective. A further discussion point is that the integration of non-state members and transnational governance actors (Bulkeley et al., 2014) can increase relevance in terms of knowledge capacity and the potential for action on emissions reductions (Hale, 2011). Authors' positions differ on what would be a good size for a club ranging from small one-digit numbers to begin the club (Hovi et al., 2017) to approximately 20 (Naím, 2009). This paper takes the following aspects as indicators for relevant membership and size of a club: a) capability and problem-solving capacity. e.g. share of the world's GHG emissions, or economic capacity; b) legitimacy. inclusion of responsible and affected actors; c) a common objective of tackling climate change mitigation.

Public goods: The production of a public good, namely governance activities to mitigate climate change, should be the main objective of a climate club (Prakash and Potoski, 2007, Green, 2015, Hovi et al., 2017). For example, clubs can actively engage in emissions reductions by carrying out climate protection projects and on-the-ground activities; they support policy making by establishing an institutional mechanism to provide GHG reductions (Potoski, 2017), such as reduction commitments or otherwise supporting countries in designing domestic regulations and mechanisms. Clubs can also enhance cooperation. They create opportunities for dialogue and bargaining by providing informal discussion arenas. They facilitate informal cooperation because there is often little pressure to finalize a formal deal (Falkner 2016b). Moreover, they create 'a playing field' where cooperation is tested informally, and technical experience gained. This can then lead to deeper cooperation (Hovi et al., 2017). This paper takes the following aspects as indicators for the creation of public goods: a) active emissions reductions; b) support of policy planning: development of policy that advances climate mitigation; c) advancing political dialogue: strategically-oriented activities that raise awareness and increase support for the topic; d) cooperation enhancement. regular exchange and coordinated work on a specific topic.

Additional benefits or 'club goods': A climate club should generate benefits or 'club goods' for its members that are additional to the common goal of climate governance (Green, 2015). Such benefits are incentives for potential members to join and keep them from dropping out (Hale, 2011, Nordhaus, 2015, Hovi et al., 2017). While these goods first and foremost benefit members, they do not have to be entirely exclusive (Hannam et al., 2017). As Falkner (2016) rightly points out, the mitigation of climate change can never be a private good. We examine whether a climate governance initiative provides additional benefits to its members and whether they see these as reason for joining or staying in the club. The paper considers the following categories of additional benefits: a) financial incentives: members gain financial advantages b) knowledge incentives, and methodologies: the dissemination of green technologies such as energy efficiency or renewable energy technologies (Potoski, 2017), members have access to the club's knowledge products or expertise; c) reputational benefits: being a member brings some kind of prestige or the prestigious name facilitates other governance activities and demonstrates a superior environmental performance of club members (Potoski, 2017); d) trust-building: participation in the club has increased trust among club members; e) co-benefits: members receive additional benefits that are produced as positive side effects from the clubs' mitigation activities, e.g., for sustainable development. 
In the following sections, the paper offers a qualitative study of the G20, the CCAC and the U2C, applying the above analytical framework. These cases were selected to represent the diversity of the climate policy landscape: They each represent different climate policy objectives, governance levels and structures. The G20 is an intergovernmental forum, the CCAC includes both state and non-state actors and the U2C is comprised of subnational governments. They differ in their years of existence; while the $\mathrm{G} 20$ builds on over twenty years of operation, the U2C is rather new with its launch in 2015. For all three cases we triangulate different data sources for insights into climate mitigation activities. While for the $\mathrm{G} 20$ study a rich sample of summit documents and action plans was available in addition to academic and grey literature, the data availability was much more limited for the CCAC and the U2C. For this reason, the latter two cases rely more heavily on expert interviews to complement available documents than the $G 20$ case study. A total of 18 semi-structured expert interviews were carried for all three cases.

\section{How do G20, CCAC and U2C contribute to international climate governance?}

\section{The G20}

The $\mathrm{G} 20$ was initiated in 1999 as a forum for finance ministers to coordinate the prevention of financial crises. It is in principal a forum for international economic cooperation. However, since 2008, it has featured meetings of state leaders and today covers a much broader set of topics. This also includes climate-related issues such as climate finance, adaptation, mitigation and clean energy transition. The inclusion of climate change on the agenda is the success of the G20 members Mexico, Korea, France and the U.S. They sought to tackle climate change as a G20 issue, based on the concern that the UNFCCC had become ineffective in generating results. China and India, in contrast, argued that climate change should remain a clear jurisdiction of the UNFCCC (Kim and Chung 2012; Kirton and Kokotsis 2015). Even though the G20 is an economic club rather than a climate club, this paper analyzes its climate governance capacity, adding to a body of literature which examines climate and energy politics of the G20 (Kim and Chung, 2012, Van de Graf and Westphal, 2011, Kirton and Kokotsis, 2015).

The $\mathrm{G} 20$ cannot take binding decisions and has no permanent secretariat. It unites a diversity of interests but seeks to formulate ambitions that all members agree with in the final communiqués of each presidency. The G20's commitment to the Paris Agreement poses a unique exception to this practice. Since 2017, summit documents featured a special clause indicating that the United States, unlike the other "G19", does not support the agreement (G20 Information Centre, 2020). The G20 presidency rotates annually and each presidency oversees the agenda for the duration of its term (Röhrkasten and Westphal, 2016, Die Bundesregierung, 2017).

The G20 has no formal connection to the UNFCCC process, nor does it appear as a negotiating block during the COPs. However, G20 members have sought to lend support to upcoming climate conferences under the UNFCCC through their communiqués. At the G20 summit in Seoul in November 2010, for instance, Japan openly pushed for a successor agreement to the Kyoto Protocol which would include all major emitters and would depart from the UN's approach of common but differentiated responsibilities. The G20 confirmed this stance at the Brisbane summit in November 2014, supporting an inclusive outcome at the upcoming COP21 
in Paris. The G20, furthermore, has called for the implementation of adaptation and finance measures, in particular the UN Green Climate Fund (Kirton and Kokotsis, 2015, Vener et al., 2019).

\section{Membership}

The $\mathrm{G} 20$ has a fixed group of members which includes 19 major industrialized and emerging economies and the European Union (EU). Meetings are exclusive to its members as well as a selected group of invited international institutions and countries (Cooper, 2010, Röhrkasten and Westphal, 2016, Sharma, 2017). The group has a high capability and problems solving capacity, as G20 countries account for 77 percent of global primary energy consumption and 82 percent of global energy-related $\mathrm{CO} 2$ emissions (International Energy Agency, 2018). Moreover, strong problem solving capacity for climate issues exists as its members are major financiers in key global governance institutions in the energy realm such as the International Energy Agency (IEA) and International Renewable Energy Agency (IRENA) as well as in UN institutions (Kim and Chung, 2012). The group also features a high degree of legitimacy through including the most responsible actors for climate change, such as China and the U.S. as the largest $\mathrm{CO} 2$ emitters and major fossil fuel-producing and consuming countries such as Saudi-Arabia and Russia. The G20 was founded to enhance exchange on economic matters. Its members are not united by a common overall climate policy objective. The G20 is therefore not a climate club, but rather an economic club with a climate governance work stream. Despite its relatively small, stable club size, it is particularly the heterogeneity of interests of its members which prevents bolder climate action. The G20's leadership role in climate protection is under constant jeopardy through climate laggard members including Russia, Saudi Arabia and, more recently, the United States. Recent G20 summits have therefore focused on non-contentious issues related to climate change, such as adaptation, infrastructural resilience and clean energy innovations (Röhrkasten et al., 2018, G20 Argentina, 2018, G20 Japan, 2019).

\section{Public good provision}

The G20 does not as such engage actively in emissions reductions activities on the ground, nor do the G20 communiqués and action plans state goals regarding concrete, measurable emission reductions. Member countries pursue their individual emissions reductions and climate policy commitments independent of the G20. Yet, some of the G20 activities do mark a joint commitment to climate protection and also seek to have a guiding role for national and international policy planning, for example through the action plans. This is showcased prominently through the 2017 Hamburg Climate and Energy Action Plan for Growth, which sought to move the G20 from its stance of merely endorsing the UNFCCC to playing a role of its own for the UNFCCC process. The G20 will strive, the action plan states, to develop their economies and energy systems in a manner compatible with the climate targets set by the PA. The plan commits the G20 members to cooperate and create learning opportunities to facilitate the implementation of each country's NDC and to support others in their NDC implementation (G20 Germany, 2017). G20 presidencies, moreover, support emission reductions by building bridges on climate-related issues between countries with different political positions and geographic circumstances, finding consensus that takes these differences into account. 
Possibly its strongest role lies in advancing political dialogue and raising awareness for climate change among the G20 members and beyond (Victor, 2017). The G20 action plans on sustainable development, climate and clean energy issues are important tools for these purposes. They receive broad international attention and help the $\mathrm{G} 20$ both assume a signaling position and act as an international agenda-setter (Röhrkasten et al., 2016). Each member individually submitted an NDC, some have also issued long-term emission reduction strategies through 2050 (Röhrkasten and Westphal, 2016, G20 Information Centre, 2020). This commitment among most members to the PA further signals non-G20 members that many major economies are committed to and are pursuing international climate targets (Vener et al., 2019).

Further, the G20 enhances cooperation on climate matters - among its formal members but also with global governance institutions and among transnational actors through regular high-level exchange, networking and coordination. One prominent example is the voluntary peer review process for fossil fuel subsidies, which is based on a 2009 declaration of intent to "phase out (...) inefficient fossil fuel subsidies" (G20 USA, 2009) under the U.S. G20 presidency. In monitoring the phase-out of fossil fuel subsidies, the G20 collaborates with institutions such as the International Energy Agency (IEA), the Organization of the Petroleum Exporting Countries (OPEC) and the Organization for Economic Cooperation and Development (OECD). Moreover, it endorses cooperation with and among transnational actors through various types of engagement formats such as Business 20 , Think20 and Civil Society20 in its governance process. The engagement formats themselves constitute a large global network of groups that deliberate - among others - on climate issues (Victor, 2017, Röhrkasten and Westphal, 2016).

Additional goods: No direct financial benefits related to climate change can be attributed to $\mathrm{G} 20$ membership. Nevertheless, the G20 structure provides knowledge incentives, enabling members to exchange best practices in the area of climate protection. The G20 activities in the realm of energy efficiency, for instance, aim explicitly at facilitating technical exchange and knowledge sharing to advance sustainable development on a global scale and reduce the environmental impact of energy use (G20 China 2016). Most importantly, the G20 membership comes with reputational benefits. The G20 as a high-level political forum has been accepted as a form of international authority, whose actions and positions receive considerable attention in the international climate policy community. The prestige of its membership is certainly conducive to international climate mitigation efforts. The regular meetings of ministers relevant to climate topics such as environment, development and energy, moreover, enable trust building and the establishment of regular communication channels. Further, through action plans, programs and communiqués and at the annual high-level meetings, G20 presidencies have linked climate change mitigation protection to other policy fields that are important to other members, including energy security, air quality issues or market developments (Röhrkasten et al., 2016, G20 USA, 2009, IPEEC, 2015). These links help to emphasize co-benefits of climate protection: Action in the area of energy security, for instance, may have positive effects both on energy systems and on national climate change mitigation activities.

\section{The CCAC}

The CCAC was established in February 2012 with the central objective of slowing the rate of near- term global warming through the reduction of short-lived climate pollutants (SLCPs) (CCAC, 2015). 'SLCPs' is a 
political term that includes black carbon, methane, hydrofluorocarbons, and tropospheric ozone. Reducing SLCPs with currently available technologies could, research shows, cut the current rate of warming in half and avoid $0.5 \mathrm{C}$ of additional warming by 2050 (UNEP, 2011). SLCPs affect both the global temperature and the local and regional air quality. CCAC's additional objectives are improving air quality and public health, promoting food security and energy efficiency as well as alleviating poverty. Being a voluntary transnational partnership, it has no legal personality and is non-treaty based. The partnership is financed by its members on a voluntary basis. Funding is pooled into a trust fund that is mostly spent on SLCP reductions related project activities as well as the CCAC secretariat (CCAC, 2014).

Launched largely independently of the UNFCCC, the emergence of the CCAC, can be seen as part of the discontent with the progress under the UNFCCC, but was by some members perceived as competitive and distracting from $\mathrm{CO}_{2}$ mitigation. However, more recently, a cooperative relationship has evolved and links between both institutions are increasing. The CCAC has supported the work of the UNFCCC, for example as technical expert under the Ad Hoc Working Group on the Durban Platform for Enhanced Action (ADP) (UNFCCC, 2014). Additionally, the CCAC actively participates in the yearly COPs and often holds its highlevel assemblies and meetings during the UNFCCC COPs. The CCAC supports its member countries, for example Mexico or Nigeria, with integrating SLCPs into their NDCs under the Paris Agreement.

Membership: The CCAC's members have the capability and problem solving-capacity for action on nearterm climate change: with large GHG emitters such as Canada, the EU, India and the USA, CCAC partners cover around $44 \%$ of the world's GHG emissions in total. The CCAC also includes many regions with high SLCP and air pollutant emissions. 18 out of the 20 most polluted cities and 6 of the 10 world's largest cities are situated in CCAC countries. Members can also be assumed to reunite economic capability to mitigate near-term climate change, as together they represent approximately $70 \%$ of the world's GDP. The CCAC can also be considered to possess a high degree of legitimacy, featuring developed countries with high historical responsibility for climate change (e.g. USA, and EU), but then also developing country members from Africa, Asia, and the Americas especially affected by air pollution problems. 44 of the 69 state partners are classified as low-income countries under the UNFCCC. The transnational character of the CCAC increases both its attractiveness to members and its relevance in terms of capacities and knowledge.

CCAC members share a common objective of making progress on SLCP mitigation. Even though there is no entrance fee or obligatory quantifiable commitments for candidates, members are expected to make monetary or non-monetary contributions, endorse the Coalition Framework and propose meaningful action on SLCPs. This open membership policy provides relatively low barriers for new members (Climate and Clean Air Coalition, 2014). However, what interviewees perceive as a challenge is that many partners are not active at all or are unwilling to commit to significant action on SLCPs and that activity of members decreased over time. In principle, this can hint at free riding, that is, members enjoying the initiative's benefits without bearing any cost or making any contributions. Still, not only increasing membership numbers suggest the attractiveness of CCAC but also many members see CCAC's specific constellation of actors as well as its new, timely and informal format as a motivation for joining. 
Although the large and heterogeneous membership increases legitimacy, it also leads to many competing interests. Partners pursue different objectives and priorities within the CCAC, which are not always easily compatible. Contentious topics include: what funding should concentrate on; whether the scope of activities should be broadened or narrowed down; whether on-the-ground-projects or international policy activities should be favored; which topics and agendas to prioritize; as well as their strategic role within the international climate and air quality policy arenas.

\section{Public goods}

The CCAC has eleven sectoral working areas, in which initiatives, country and non-state partners work together. Some of the implemented projects actively achieve SLCP emissions reductions. For example, the CCAC reports a reduction of 12,668 tons of methane emissions from the oil and gas sector in 2016-2017 (CCAC, 2017a). The projects also often involve capacity building and training measures for the local population. These projects are best practices to be transferred to other world regions and sectors, but rather stop short of achieving emissions reduction at large scale. In many cases, the data is insufficient to make a robust, quantitative accounting of emissions reductions based on the coalition's activities. Nevertheless, many of the activities carried out by the CCAC may lead to emissions reductions in the future.

The CCAC has also successfully supported policy planning, through the development of SLCP policies at the national and local level. According to CCAC'S reporting, it has had a role in the development and adoption of eleven national laws, regulations or standards in the areas of diesel, waste and bricks policies in at least eight different countries (CCAC, 2017a). The CCAC further supports international environmental agreements, such as the Montreal Protocol with the Kigali Amendment and the PA. For instance, it promotes SLCPs reductions in these agreements through its publications, events and High Level Assemblies with government officials (CCAC, 2018a) or by giving technical support to the inclusion of SLCPs in NDCs.

A major strength of the CCAC is advancing political dialogues and raising the awareness on near-term climate change and SLPCs. Activities such as its Ministerial Roundtables and the regularly-held High Level Assemblies with their political communiqués also increase the attention on SLCPs internationally (CCAC, 2017b). SLCPs have appeared on the agendas of the G7, and the General Assembly of the Parliamentary Confederation of the Americas. A majority of partners sees a main strength in the CCAC's work to establish SLCPs as a topic per se, and at different governance levels. It brings SLCPs to the political agenda and gives a neglected 'climate' topic attention at the national and international level. Another major asset of the CCAC lies in cooperation enhancement. It provides a strong cooperation and assembling a large wellinformed network. The Coalition is built on the regular exchange on scientific and technical topics paired with a very strong scientific basis provided by CCAC's Scientific Advisory Board and non-state partners.

The CCAC produces a number of additional benefits for its members. Financial support, in the form of funding for SLCPs implementation or capacity building projects is provided, first and foremost for developing countries. It can also have a facilitating role in generating funding from other sources such as the UN Green Climate Fund or the private sector. Knowledge incentives and methodologies, such as technical support and expertise on SLCP reductions are among CCAC's main assets. For example, the Long- 
range Energy Alternatives Planning - Integrated Benefits Calculator (LEAP-IBC) is a planning tool that helps governments to assess GHG, SLCPs and other air pollutant emissions (Stockholm Environment Institute, 2018). Further reputational benefits originate from CCAC's perceived legitimacy function. For example, a labelled 'CCAC' activity may provide prestige and special recognition of climate policy projects. Another additional benefit is trust-building among members. CCAC meets at least twice per year and partners cooperate closely in initiatives. Such positive member relationships can yield advantages in other governance institutions or in bilateral political and economic relations.

\section{The Under2 Coalition}

The Under2 Coalition (U2C) started with a Memorandum of Understanding (MoU) (U2C, n.d. a) in the run-up to COP21 and the Paris Agreement in May 2015, based on an initiative from the U.S. state California and the German state of Baden-Württemberg. The objective is to meet the international target of keeping global warming under $2{ }^{\circ} \mathrm{C}$, aiming at 80 to 95 percent reductions below 1990 levels and/or per capita annual emissions of less than 2 metric tons of carbon dioxide-equivalent by 2050 (U2C, n.d. a). The U2C is administrated by a secretariat, operated by Think Tank The Climate Group. It has a Steering Group and the Co-Chairs as strategic bodies (U2C, 2018a).

The U2C is closely connected to the PA and the UNFCCC process even though sub-national jurisdictions figure as 'non-party stakeholders' and have no negotiation authority here. The U2C presented its initial MoU at the COP 21. Through its presence at the COPs and its activities, it aims to accelerate official negotiations. Also, most of the annual member meetings take place at the COPs. However, some members perceive that a stronger representation and recognition in the official process under the UNFCCC would support U2C's objectives.

Membership: The U2C is constantly growing: so far, 220 jurisdictions in 43 countries have signed on. Signatories are state, regional, provincial, city and local governments and administrative authorities. National governments can support the objectives formulated in the MoU and provide financial resources or expertise to the U2C (U2C, 2018b). Its fast growth poses challenges to administrative management in terms of determining priorities and substantiating activities.

The U2C's size and diversity support its problem solving capacity: It represents 1.3 billion people and 43 percent of the global economy (U2C, 2018c). Large subnational actors both responsible or especially vulnerable GHG emitters such as California, Baden-Württemberg, and regions in India and in China are part of the coalition (U2C, 2018b). Especially its focus on subnational actors adds to the legitimacy of the U2C. Subnational actors are left out of the official UNFCCC process, yet they may be better prepared to cope with specific local concerns. Thus, in many cases they open a window for activity where national action fails.

U2C members are united under a common climate change mitigation objective, to be achieved by each member with individually set $\mathrm{GHG}$ reduction targets. The $\mathrm{U} 2 \mathrm{C}$ has a relatively open membership policy, but members have to demonstrate how they plan to achieve the 'under $2{ }^{\circ} \mathrm{C}^{\prime}$ goal (U2C, n. d.b). Members of the U2C show very different degrees of activity; the 2018 report displays that only 31 members reported policy action (U2C, 2018d). The interviews carried out for this research revealed that only a small circle of 
members is very active in the $\mathrm{U} 2 \mathrm{C}$, which on the one hand can drive quicker actions. But on the other hand it could hint at a situation of free riding by some members, who benefit from the U2C label but make no contributions. Another challenge to the group's climate ambitions is the strong heterogeneity of the members: size and capacity, political, structural and legal context, including the significantly varying autonomy with which decisions can be adopted,. This hinders the transferability of policy instruments and commitments, as well best practices.

\section{Public goods}

U2C engages in emission reductions activities in several different ways. To sign on to membership, jurisdictions need to set GHG reduction targets in line with the Under2 MOU (U2C, 2019). They perceive their signature on the Under2 $\mathrm{MoU}$ as a reputational commitment that helps to drive activity. In spite of its legally non-binding character, it sets a concrete target for its signatories. Members are asked to report on their GHG emissions and climate actions in the annual disclosure reports (U2C, n. d.b). Members are encouraged to do a data inventory and the coalition provides an analytical tool to evaluate policies (U2C, 2018e). Members regard the reporting structure as a main success of U2C.

Otherwise, the club engages more indirectly in emissions reductions, through the realizations of diverse coordination and cooperation activities. The U2C supports subnational policy planning. It seeks to help its members to plan the policy pathway towards reaching this goal, e.g. through initiatives, such as the Pathway Project or Peer Learning Project (U2C, 2020b, U2C, 2020a). Also, the U2C seeks to stir action in key areas, such as through its Zero Emissions Vehicles or the Industry Transition Platform initiatives (U2C, 2020c). Yet, many of these projects have only been launched recently and it is difficult to evaluate their concrete results or effectiveness. Likely, the most important success of U2C is advancing political dialogue and the empowerment of a group of actors that has been somewhat neglected under the international policy process of the UNFCCC. For example, it raises national and international awareness of the potential of subnational climate change mitigation activities and their contribution on a global scale. The large network of the U2C enhances cooperation between businesses, governments and non-governmental institutions, for instance, through the international conferences it organizes (U2C, 2018a, U2C, 2018f).

\section{Additional goods}

The U2C established the "Future Fund" to financially support members' state-level climate action in developing and emerging economies (U2C, 2019). However, to date the fund holds relatively small amounts of money. For example in 2018, it received donations of some 152,000 USD (U2C, $2018 \mathrm{~g}$ ). Interviews suggest that the availability of funding for projects could be decisive for the future of U2C. A non-material incentive to join the coalition is knowledge provision. The U2C has established a peer learning and knowledge sharing platform which its members perceive as a major asset. The U2C secretariat facilitates the transfer of knowledge on mitigation actions, for instance, through organizing background briefings, communication and translation services (U2C, $2018 \mathrm{~h}$ ). Also, some reputational benefits can be expected from $\mathrm{U} 2 \mathrm{C}$ membership, as the $\mathrm{U} 2 \mathrm{C}$ is increasingly renowned in the international climate policy landscape. But also domestically, being a member can mean a gain in recognition from the national government. The 
'label' U2C gives those policy makers active in the initiative the leverage to exercise more pressure on their national governments, making them act on climate change topics. Moreover, belonging to a renowned climate initiative can incentivize members to live up to this name. It is difficult to estimate to which degree trust-building has the potential to unfold as a significant U2C benefit. Signatories and endorsers do meet annually at the COPs or at other major climate events such as the Climate Action Summit establishing regular communication channels among the members (U2C, 2018a).

\section{G20, Ccac And U2c In Comparative Perspective}

Overall, we find that G20, CCAC and U2C make a relevant contribution to international climate governance and further support achieving the PA's objectives. The three initiatives differ significantly in how they deal with climate change as a topic: While the G20 was launched with a clear economic focus with energy and climate issues only emerging on its agenda in 2009, the CCAC and the U2C center on mitigation of global warming and further environmental aspects.

What all three initiatives have in common is that their activities on climate change mitigation were a response to the perceived failure of the UNFCCC process and a conviction that extra action would be necessary to cope with climate change. All three act outside the official UNFCCC negotiation process and their relationship to the UNFCCC is complementary and not competing. The U2C is very closely linked through its direct reference to the Paris Agreement's objectives; the CCAC has ties through active cooperation and to some degree overlapping contents. The G20's work on climate and energy matters has only very few direct procedural connections beyond an official endorsement of the UNFCCC. It eventually assumed a role as a "pacemaker" for the COPs once it included climate issues on its agenda. Due to the prominence and international influence of its members, its own climate agenda has been able to support consensus within the UNFCCC. For example, through its statement of support for the inclusion of all major emitters in a successor agreement to the Kyoto Protocol, the G20 contributed to preparing a common language that would be pursued in the negotiations of the Paris Agreement in 2015 (Kirton and Kokotsis, 2015).

In general, we find that these clubs have a role in climate governance in several ways, however, the strength of all three lies in indirectly achieving and preparing emission reductions.

All three initiatives build on the willingness of individual members to realize emissions reductions; they do not foresee emissions reduction pathways for their members. Only the $\mathrm{U} 2 \mathrm{C}$ has set relatively concrete goals for members to achieve. However, at least for the CCAC and the U2C the voluntary character of the club is part of its appeal. Both the CCAC and the U2C have to some degree actively engaged in climate project activities. Although some of these activities directly reduce emissions on-the-ground, they can be seen as best practices and many focus on capacity building for climate protection.

A number of activities can contribute to preparing the playing field for future emissions reductions. Likely the central value for these three initiatives in climate governance has been that of strengthening a strategic dialogue through influencing political agendas and raising awareness in specific contexts and

Page $14 / 23$ 
communities. They have raised different facets of the climate change problematic to a high governmental level, thereby gaining support for climate policies and creating more favorable political conditions for their implementation. The CCAC has been very successful in raising awareness regarding the importance of SLCP reductions for climate, air quality and sustainable development. This awareness-raising is especially important for SLCPS, which for a long time had been regarded as only an air quality topic. Members of U2C see the creation of national and international awareness of the potential of subnational climate change mitigation activities and their contribution on a global scale as its largest success. Such increased awareness has provided an avenue for action from actors that are often underestimated in the international climate policy landscape. Within the G20, climate change has been a contested issue. Nevertheless, the G20's recent commitments to climate and sustainable energy issues raise awareness not only within the group. Coming from the world's major economies, energy consumers and climate polluters, climate commitments among the members send a signal to all non-G20 countries about the importance and future direction of climate protection.

In many cases, the three clubs incentivize policies planning and capacity building. The CCAC has successfully supported local and national SLCP policy making, such as national laws, regulations, and standards, which promise to reduce emissions in the future. The U2C is actively contributing to reporting and measurements on climate actions taken in subnational jurisdictions. It has a value in providing examples and indicating pathways to subnational actors that might not have been accessible without the existence of the U2C. A strength of both CCAC and U2C is also capacity building and 'learning by example'. The $\mathrm{G} 20$ operates at an overarching level, when suggesting certain practices or pathways for its members. It incentivizes policy implementation through means such as commissioning (monitoring) reports from international institutions such as IEA on fossil-fuel phase out or energy efficiency improvements. Overall, these initiatives can be expected to build the capacity for mitigation opportunities additional to those promised under the PA.

An important function of our three cases lies in the creation of a network and enhancement of deeper cooperation. For the G20 cooperation has become the main function. The role of CCAC and U2C can also be seen as orchestrators as they bring actors of different governmental levels and sectors together and coordinate and direct their actions. All three clubs build common narratives for climate protection and mutually reinforcing implementation of the Paris Agreement, constituting preconditions for the international climate policy process under the UNFCCC and beyond.

All three, G20, CCAC and U2C provide sufficient club goods to make members join or stay in the club. However, in the $\mathrm{G} 20$, climate change mitigation is only one issue among many, the glue holding the club together being the prominence of its members rather than climate change benefits. For the CCAC and U2C, we found additional benefits, which first of all benefit their members, but ultimately suit the common objective of climate change mitigation. For example, CCAC and U2C have a strong emphasis on technological exchange, capacity and knowledge building. The G20, in spite of its relevance as actor in the international climate landscape, is more challenging to fit into our analytical framework. It does, however, create an institutional body, holds regular meetings and fosters exchange that can have a strong role in 
enhancing trust between members, which also can pave the way for future action on climate change. Further, all three provide members with reputational benefits, and the creation of a 'label' or authority.

A 'co-benefit'these three clubs have in common is that their focus has become more integrative: climate change is increasingly coupled with other topics such as development, energy security or public health. They bring climate change topic into other policy frameworks and contexts; for example addressing climate change became one of the Sustainable Development Goals (SDGs), adopted in 2015 under the UN 2030 Agenda for Sustainable Development.

Last, but not least, the initiatives' membership constellation generally supports, but also challenges the climate policy potential of our three clubs: Looking at membership constellations, the G20 is the only initiative in line with the assumptions of the classic clubs concept in terms of membership size. Both CCAC and $\mathrm{U} 2 \mathrm{C}$ have far more than one hundred members each and are still growing, pursuing a very open membership policy. CCAC is the only transnational initiative with non-governmental members. All include relevant members in terms of responsibility and vulnerability to climate change and altogether with a high problem solving capacity in terms of GHG and economic capacity. The U2C differs in that it focuses primarily on sub-national jurisdictions. However, its members are provinces, states and cities from the same countries the CCAC and the $\mathrm{G} 20$ draw their membership from and many of the $\mathrm{G} 20$ and CCAC country members support the $\mathrm{U} 2 \mathrm{C}$. In difference to the $\mathrm{G} 20$, the CCAC and the $\mathrm{U} 2 \mathrm{C}$ are united through a common climate change related purpose. Nevertheless, all three face the challenge of competing membership interests, and to some degree, very diverse degrees of commitment among members.

\section{Conclusion}

We have argued that the main climate governance contribution lies in preparing the playing field and creating alternative incentive structures for climate change mitigation. Climate club conceptualizations prove useful as an analytical tool to structure the analysis of the different cases, its broad interpretation enabling its application on many types of initiatives that shape international climate governance today. However, while the $\mathrm{G} 20$ is the only club in the economic sense its main objective is not climate protection. Especially CCAC and U2C resemble what previous research determined as voluntary or even pseudo clubs pursuing a strong focus as technical forum. The building blocks concept by Stewart et al. (2017) supports a more specific understanding of nature of the contribution of these initiatives.

This paper has also observed characteristics that challenge the governance assets of the three cases. Common to all three and independent of their diverging sizes, all have over their years of existence faced somewhat competing interest between members. Diverging priorities and objectives within the clubs challenges their effectiveness and their abilities to make decisions. In the CCAC and U2C the heterogeneity of objectives comes as a by-product of their large size, which stands in contrast to the initially claimed purpose of clubs to provide quicker progress than the large forum such as the UNFCCC. Further, this has led to very different degrees of engagement within the club. But also the history of the $G 20$ has shown that the degree of commitment on climate policy depends highly on the respective presidency. Singular interests were able to block more climate friendly decisions in the past, preventing a clear positioning as 'high 
ambition coalition' for climate protection. Within the CCAC and the U2C appears to be a small group of especially active members, and many others with a low degree of commitment.

All three clubs have in the past also been subject to structural challenges, such as government changes, which can have severe consequences on the club's agenda; in the case of the CCAC, funding from the USA was no longer secured after the 2017 change in government. The latter also affected the G20's climate agenda as the U.S. was no longer on board with multilateral climate ambitions. In the U2C, formerly very active member Ontario has become inactive after the government turnover in 2018.

Overall, the comparative analysis of non-traditional climate policy initiatives and their overlaps merits further investigation, especially as the number of initiatives is growing steadily and new actor constellations are emerging. In particular because of the obvious action gap for achieving the $1.5^{\circ} \mathrm{C}$ target, it is important to understand more about the contribution club-like formats can make toward pushing forward the PA agenda.

\section{Declarations}

\section{Data availability}

\section{Interviews}

Interview 1: 04.05 .2018 (preliminary talk), interview 2: 26.04.2018, interview 3: 21.08.2018, interview 4:29.08.2018, interview 5: 03.09.2018, interview 6: 02.10.2018, interview 7: 19.09.2018, interview 8: 04.10.2018, interview 9: 05.10.2018, interview 10: 09.10.2018, interview 11:09.10.2018, interview 12: 12.10.2018, interview 13: 17.10.2018, interview 14: 21.09.2018, interview 15: 11.06.2019, interview 16: 06.08.2019, interview 17: 91.08.2019, interview 18: 20.08.2019

Interviews were carried out with country and non-state members from the CCAC and the CCAC Secretariat; U2C members and the U2C Secretariat; further scientific experts on the G20.

Funding (not applicable)

\section{Conflicts of interest/Competing interests}

The authors declare that they have no conflict of interest.

\section{Availability of data and material}

The datasets generated during the current study through expert interviews, such as interview transcripts and notes, are not publicly available in order to keep individuals' privacy, but are available from the corresponding author on reasonable request.

Code availability (not applicable)

\section{Acknowledgments}


We would like to acknowledge the support from Konrad Gürtler and Kathleen Mar as well as fruitful discussions with the members, Secretariat(s) and experts of CCAC, G20 and U2C.

\section{References}

ABBOTT, K. W. 2012. The transnational regime complex for climate change. Environment and Planning C: Government and Policy, 30, 571-590.

ABBOTT, K. W., GENSCHEL, P., SNIDAL, D. \& ZANGL, B. 2015. International organizations as orchestrators, Cambridge, New York, Cambridge University Press.

BIERMANN, F., PATTBERG, P., VAN ASSELT, H. \& ZELLI, F. 2009. The fragmentation of global governance architectures: A framework for analysis. Global Environmental Politics, 9, 14-40.

BUCHANAN, J. M. 1965. An economic theory of clubs. Economica, 32, 1-14.

BULKELEY, H., ANDONOVA, L. B., BETSILL, M. M., COMPAGNON, D., HALE, T., HOFFMANN, M. J., NEWELL, P., PATERSON, M., VANDEVEER, S. D. \& ROGER, C. 2014. Transnational climate change governance, New York, Cambridge University Press.

CCAC. 2014. Guidelines \& rules of engagement for coalition partners, actors and implementers compilation of decisions [Online]. Available: http://www.ccacoalition.org/en/resources/climate-and-cleanair-coalition-ccac-guidelines-rules-engagement [Accessed 01.11.2018].

CCAC. 2015. 5-year strategic plan (2020) [Online]. Climate and Clean Air Coalition. Available: http://www.ccacoalition.org/fr/resources/climate-and-clean-air-coalition-five-year-strategic-plan [Accessed 16.10.2019].

CCAC. 2017a. Annual report 2016-2017[Online]. Climate and Clean Air Coalition. Available: http://www.ccacoalition.org/en/resources/climate-clean-air-coalition-annual-report-2016-2017 [Accessed 15.10.2018].

CCAC. 2017b. Bonn communique [Online]. Climate and Clean Air Coalition. Available: http://ccacoalition.org/en/resources/bonn-communique [Accessed 04.04.2019].

CCAC. 2018a. Annual report 2017-2018 [Online]. Climate and Clean Air Coalition. Available: http://ccacoalition.org/en/resources/climate-clean-air-coalition-2017-2018-annual-report [Accessed 04.04.2019].

CHAN, S., ELLINGER, P. \& WIDERBERG, O. 2018. Exploring national and regional orchestration of non-state action for $\mathrm{a}<1.5^{\circ} \mathrm{C}$ world. International Environmental Agreements: Politics, Law and Economics, 18, 135152.

CLIMATE AND CLEAN AIR COALITION. 2014. Guidelines \& rules of engangement for coalition partners, actors and implementers - compilation of decisions [Online]. Available: 
http://www.ccacoalition.org/en/resources/climate-and-clean-air-coalition-ccac-guidelines-rules-engagement [Accessed 01.11.2018].

COOPER, A. J. 2010. The G20 as an improvised crisis committee and/or a contested 'steering committee' for the world. International Affairs, 86, 741-757.

DIE BUNDESREGIERUNG. 2017. Argentinien übernimmt G20-Vorsitz [Online]. Available: https://www.bundesregierung.de/breg-de/aktuelles/argentinien-uebernimmt-g20-vorsitz-440086 [Accessed 03.03.2020].

FALKNER, R. 2016. A minilateral solution for global climate change? On bargaining efficiency, club benefits, and international legitimacy. Perspectives on Politics, 14, 87-101.

FALKNER, R., STEPHAN, H. \& VOGLER, J. 2010. International climate policy after Copenhagen: Towards a 'building blocks' approach. Global Policy, 1, 252-262.

G20 ARGENTINA. 2018. G20 Leaders' declarationBuilding consensus for fair and sustainable development [Online]. Available: http://www.g20.utoronto.ca/2018/buenos_aires_leaders_declaration.pdf [Accessed 21.11.2019].

G20 GERMANY. 2017. G20 Hamburg Climate and Energy Action Plan for Growth [Online]. Available: http://www.g20.utoronto.ca/2017/2017-g20-climate-and-energy.html [Accessed 21.11.2019].

G20 INFORMATION CENTRE. 2020. G20 Summits [Online]. Available: http://www.g20.utoronto.ca/summits/index.html [Accessed 15.12.2020].

G20 JAPAN. 2019. G20 Osaka Leaders' Declaration [Online]. Available: http://www.g20.utoronto.ca/2019/FINAL_G20_Osaka_Leaders_Declaration.pdf [Accessed 21.11.2019].

G20 USA. 2009. Leader's Statement. The Pittsburgh Summit [Online]. Available:

http://www.g20.utoronto.ca/2009/2009communique0925.html [Accessed 21.11.2019].

GRAICHEN, J., HEALY, S., SIEMONS, A., HÖHNE, N., KURAMOCHI, T., GONZALES-ZUÑIGA, S., STERL, S., KERSTING, J. \& WACHSMUTH, J. 2016. International Climate Initiatives - A way forward to close the emission gap? Initiatives' potential and role under the Paris Agreement. Dessau-Roßlau: Umweltbundesamt.

GREEN, J. F. 2015. The strength of weakness: Pseudo-clubs in the climate regime. Climatic Change, 144, 4152.

GUPTA, A., PISTORIUS, T. \& VIJGE, M. J. 2016. Managing fragmentation in global environmental governance: The REDD+ Partnership as bridge organization. International Environmental Agreements: Politics, Law and Economics, 16, 355-374.

HALE, T. 2011. A climate coalition of the willing. The Washington Quarterly, 34, 89-101. 
HANNAM, P. M., VASCONCELOS, V. V., LEVIN, S. A. \& PACHECO, J. M. 2017. Incomplete cooperation and cobenefits: deepening climate cooperation with a proliferation of small agreements. Climatic Change, 144, 6579.

HERMWILLE, L. 2018. Making initiatives resonate: how can non-state initiatives advance national contributions under the UNFCCC?

HOVI, J., SPRINZ, D. F., SAELN, H. \& UNDERDAL, A. 2017. The club approach: A gateway to effective climate co-operation? British Journal of Political Science, 1-26.

IACOBUTA, G., DUBASH, N. K., UPADHYAYA, P., DERIBE, M. \& HÖHNE, N. 2018. National climate change mitigation legislation, strategy and targets: A global update. Climate Policy, 18, 1114-1132.

INTERNATIONAL ENERGY AGENCY 2018. G20. Global Engagement.

IPEEC. 2015. Report on the G20 Energy Efficiency Action Plan Voluntary Collaboration on Energy Efficiency. Report to the G20 on 2015 Outcomes of Work Streams [Online]. Available:

https://www.ief.org/_resources/files/events/g20-energy-ministers-meeting-and-conference-on-energyaccess-in-sub-saharan-africa/report-on-g20-energy-efficiency-action-plan-2015-outcomes.pdf [Accessed 03.03.2020].

KIM, J. A. \& CHUNG, S.-Y. 2012. The role of the G20 in governing the climate change regime. International Environmental Agreements: Politics, Law and Economics, 12, 361-374.

KIRTON, J. J. \& KOKOTSIS, E. 2015. The Global Governance of Climate Change: G7, G20, and UN Leadership, Ashgate Publishing, Ltd.

MICHAELOWA, K. \& MICHAELOWA, A. 2017. Transnational Climate Governance Initiatives: Designed for Effective Climate Change Mitigation? International Interactions, 43, 129-155.

NAÍM, M. 2009. Minilateralism: The magic number to get real international action. Foreign Policy, 136-135.

NORDHAUS, W. 2015. Climate clubs: Overcoming free-riding in international climate policy. The American Economic Review, 105, 1339-1370.

OLSON, M. 1971. Increasing the incentives for international cooperation. International Organization, 25, 866-874.

OSTROM, E. 2010. Polycentric systems for coping with collective action and global environmental change. Global Environmental Change, 20, 550-557.

PATTBERG, P. \& WIDERBERG, O. 2017. The Climate Change Regime. In: VON STORCH, H. (ed.) Oxford Research Encyclopedia of Climate Science. Oxford University Press.

POTOSKI, M. 2017. Green clubs in building block climate change regimes. Climatic Change, 144, 53-63. 
PRAKASH, A. \& POTOSKI, M. 2007. Collective action through voluntary environmental programs: A club theory perspective. Policy Studies Journal, 35, 773-792.

RÖHRKASTEN, S., THIELGES, S., HÜBNER, C. \& HELGENBERGER, S. 2018. Germany-Latin America: Fostering Strategic Alliances for a Global Energy Transition. Berlin: Konrad Adenauer Stiftung/IASS.

RÖHRKASTEN, S., THIELGES, S. \& QUITZOW, R. 2016. Introduction and main insights from the study. In: RÖHRKASTEN, S., THIELGES, S. \& QUITZOW, R. (eds.) Sustainable energy in the G20: Prospects for a global energy transition.

RÖHRKASTEN, S. \& WESTPHAL, K. 2016. The G20 and its Role in Global Energy Governance. Sustainable Energy in the G20: Prospects for a Global Energy Transition.

SHARMA, A. 2017. The road to Hamburg: A reflection on the achievements of G20. Indian Council of World Affairs.

STEWART, R. B., OPPENHEIMER, M. \& RUDYK, B. 2017. Building blocks: A strategy for near-term action within the new global climate framework. Climatic Change, 144, 1-13.

STOCKHOLM ENVIRONMENT INSTITUTE. 2018. The long-range energy alternatives planning - Integrated Benefits Calculator (LEAP-IBC) [Online]. Available: http://www.ccacoalition.org/en/resources/long-rangeenergy-alternatives-planning-integrated-benefits-calculator-leap-ibc-factsheet [Accessed 04.04.2019].

U2C. 2018a. Under2 Coalition Governance - Terms of Reference [Online]. Available:

https://www.under2coalition.org/sites/default/files/under2_coalition_governance_tor_may_2018.pdf [Accessed 03.03.2020].

U2C. 2018b. Our Members [Online]. Available: https://www.under2coalition.org/members [Accessed 03.03.2020].

U2C. 2018c. About the Under2 Coalition [Online]. Available: https://www.under2coalition.org/about [Accessed 21.11.2019].

U2C. 2018d. Sharing Success: The Under2 Policy Action Map has launched [Online]. Available: https://www.under2coalition.org/news/sharing-successes-under2-policy-action-map-has-launched [Accessed 21.11.2019].

U2C. 2018e. Protecting Quintana Roo's coastal infrastructure by insuring nature. [Online]. Available: https://www.under2coalition.org/sites/default/files/under2_coalition_case_study_quintana_roo_english.pdf [Accessed 21.11.2019].

U2C. 2018f. Energy Transition Platform [Online]. Available: https://www.under2coalition.org/EnergyTransitionPlatform [Accessed 21.11.2019]. 
U2C. 2018g. Accelerating climate action in developing countries. Future Fund Progress Report 2018 [Online]. Available: https://www.under2coalition.org/news/accelerating-climate-action-developing-regions [Accessed 07.08.2020].

U2C. 2018h. Governance [Online]. Available: https://www.under2coalition.org/under2-governance [Accessed 21.11.2019].

U2C. 2019. Future Fund and Progress Report 2019 [Online]. Available: https://www.under2coalition.org/sites/default/files/future_fund_progress_report_2019.pdf [Accessed 07.08.2020].

U2C. 2020a. Pathways [Online]. Available: https://www.under2coalition.org/project/pathways [Accessed 07.08.2020].

U2C. 2020b. Policy Action [Online]. Available: https://www.under2coalition.org/project/policy-action [Accessed].

U2C. 2020c. Industry Transition Platform [Online]. Available: https://www.under2coalition.org/project/industry-transition-platform [Accessed 07.08.2020].

U2C. n. d.b. Signatory and Endorser Criteria and Process [Online]. Available: https://www.under2coalition.org/sites/default/files/under2_coalition_signatory_and_endorser_criteria_.pdf [Accessed 03.03.2020].

U2C. n.d. a. Global Climate Leadership Memorandum of Understanding (MOU) [Online]. Available: https://www.theclimategroup.org/sites/default/files/under2-mou-with-addendum-english-us-letter.pdf [Accessed 19.11.2019].

UN ENVIRONMENT. 2018. Emissions gap report 2018 [Online]. United Nation Environment Programme. Available: http://wedocs.unep.org/bitstream/handle/20.500.11822/26895/EGR2018_FullReport_EN.pdf? sequence $=1$ \&isAllowed $=y$ [Accessed 04.04.2019].

UNEP 2011. Near-term climate protection and clean air benefits: Actions for controlling short-lived climate forcers. In: KUYLENSTIERNA, J., ZUCCA, M., AMANN, M., CARDENAS, B., CHAMBERS, B., KLIMONT, Z., HICKS, K., MILLS, R., MOLINA, L. \& MURRAY, F. (eds.). Nairobi, Kenya.

UNFCCC. 2014. Expert meeting: ADP technical expert meetings: Non-CO2 greenhouse gases. [Online]. Available: https://unfccc.int/process-and-meetings/conferences/past-conferences/bonn-climate-changeconference-october-2014/events-and-programme/mandated-events/adp-technical-expert-meetings-non-co2greenhouse-gases [Accessed 21.11.2019].

VAN DE GRAF, T. \& WESTPHAL, K. 2011. The G8 and G20 as global steering committees for energy: Opportunities and constraints. Global Policy, 2. 
VENER, J., FRANSEN, T., LEVIN, K., BAUMWOLL, J., ELLIOTT, C. \& ROSS, K. 2019. SCALING UP AMBITION: LEVERAGING NATIONALLY DETERMINED CONTRIBUTIONS AND LONG-TERM STRATEGIES TO ACHIEVE THE PARIS AGREEMENT GOALS [Online]. Available:

http://www.indiaenvironmentportal.org.in/files/file/scaling-up-ambition.pdf [Accessed 03.03.2020].

VICTOR, D. G. 2015. The case for climate clubs [Online]. International Centre for Trade and Sustainable Development (ICTSD) Available: http://www.e15initiative.org/ [Accessed 27.07.2018].

VICTOR, D. G. 2017. Three-dimensional climate clubs: Implications for climate cooperation and the G20. Climate and Energy: Think Piece. ICTSD International Centre for Trade and Sustainable Development.

VICTOR, D. G. \& KEOHANE, R. O. The Regime Complex for Climate Change. APSA 2010 Annual Meeting Paper, 2010.

WIDERBERG, O. \& STENSON, D. E. 2013. Climate clubs and the UNFCCC. Fores Study, 3, 1-52. 